\title{
Fruit fly (Diptera: Tephritidae) assemblage in a feijoa orchard in Santa Catarina State, Brazil
}

\author{
Ensamble de moscas de las frutas (Diptera: Tephiritidae) en huerto de feijoa en el Estado de Santa Catarina, Brasil
}

\author{
JOATAN MACHADO DA ROSA', MARCELO ZANELATO NUNES ${ }^{1}$, MARI INÊS CARISSIMI BOFF², FLÁVIO \\ ROBERTO MELLO GARCIA ${ }^{3}$, PEDRO BOFF ${ }^{4}$ and CLÁUDIO ROBERTO FRANCO ${ }^{2}$
}

\begin{abstract}
Fruit flies cause economically important damage on several cultivated and native South American fruit trees. Hence, it is important to understand the population dynamics of these insects. This study aimed to characterize the assemblage and population fluctuations of fruit flies in a feijoa (Acca sellowiana) orchard in Lages, Santa Catarina State, Brazil from September 2009 to May 2012. Captures of flies were made with McPhail traps baited with hydrolyzed protein. Evaluations and bait change were performed weekly. A total of 2,197 flies were captured (957 males and 1,240 females). Analysis of abundance, constancy, dominancy and frequency showed that Anastrepha fraterculus was the main species captured; it was considered to be very frequent, constant and highly dominant throughout the study period. The orchard presented low equitability, low diversity, and high dominance of $A$. fraterculus during the three fruit seasons evaluated. No correlation was found between climatic factors and population levels of $A$. fraterculus.
\end{abstract}

Key words: Insecta, Myrtaceae, diversity, monitoring, faunal index.

\begin{abstract}
Resumen: Las moscas de las frutas causan daños económicos en una amplia gama de frutos sudamericanos, cultivados o nativos. Por lo tanto, se hace importante conocer las especies y las dinámicas poblacionales de estos insectos. Este estudio tuvo como objetivo caracterizar el ensamble y la fluctuación de las moscas de las frutas en un huerto de feijoa (Acca sellowiana) en la región de Lages, Brasil, entre 2009 y 2012. Se utilizaron trampas tipo Mcphail y proteína hidrolizada como cebo para captura de las moscas. Se capturó un total de 2.197 moscas (957 machos y 1.240 hembras). A través de los análisis de abundancia, constancia, dominancia y frecuencia se constató que Anastrepha fraterculus fue la especie predominante, considerada muy frecuente, constante y altamente dominante en todo el período de evaluación. El huerto de feijoa mostró baja equidad, baja diversidad y alta dominancia de moscas de las frutas, en las tres cosechas evaluadas. No se encontró correlación significativa entre los factores climáticos y los niveles poblacionales de $A$. fraterculus.
\end{abstract}

Palabras clave: Insecta, Myrtaceae, diversidad, monitoreo, índices faunísticos.

\section{Introduction}

Feijoa, Acca sellowiana (Berg) Burret belongs to the Myrtaceae family; it is native to South America and is widely dispersed over the Brazilian southern highlands and northeastern Uruguay. This species is popularly known as "goiabeira-serrana", "goiabeira-da-serra" or feijoa. In English it is called "pineapple guava" (Ducroquet et al. 2000). Its fruits have a peculiar odor and taste, and its commercial cultivation is encouraged because it is considered to be the "plant of the future" by the Department of Biodiversity and Conservation of the Ministry of Environment (MMA 2007). The feijoa is mostly cultivated in small areas; despite this, the fruits have a great economic potential because juice, jam, ice cream, liqueurs and other products can be obtained from its fruits (Ducroquet et al. 2000). Countries such as New Zealand (Thorp and Bieleski 2002) and China (Zhang et al. 2010) have invested in the design and development of technologies for A. sellowiana crops.

The fruit flies of the Tephritidae family, mainly those of the genera Anastrepha and Ceratitis, are one of the major pests of temperate and tropical fruit trees in Brazil. These insects are economically important both for the variety of native hosts and their wide distribution, which occurs from Mexico to Southern Argentina (Garcia 2009).

According to FAO (Food and Agriculture Organization), losses caused by Tephritidae reach US\$ 1.7 billion every year, and $10 \%$ of such losses occur in Brazil (FAO 2013). The Santa Catarina State has a richness of 70 species of fruit flies (Garcia et al. 2002), and 25 of these species belong to the genus Anastrepha (Zucchi 2008). Within this genus, Anastrepha fraterculus (Wiedemann, 1830) is the species of greater economic importance (Garcia et al. 2003). This species is distributed throughout 22 Brazilian states, with 114 host plant species associated with 28 botanic families (Zucchi 2008). Feijoa is a primary host of $A$. fraterculus (Luckmann 2009), which is considered to be the main pest of this fruit tree.

Females of fruit flies puncture in fruits causing the death of cells near the oviposition site, resulting in fruit deformations. Larvae cause the greatest losses. They destroy the fruit pulp, accelerating maturation and provoking early fruit drop (Aguiar-Menezes and Menezes 2000). These flies move from one host to another, depending on availability of fruits.

There is no information on infestation level, phenology and taxonomy of species related to feijoa. Thus, further

\footnotetext{
${ }^{1} \mathrm{Ph}$. D. Laboratory of Entomology, University of Santa Catarina State, Agronomy Department, 88520-000 Lages, SC, Brazil, joatanmachado@gmail. com. ${ }^{2}$ Ph. D. Laboratory of Entomology, University of Santa Catarina State, Agronomy Department, 88520-000 Lages, SC, Brazil. ${ }^{3}$ Dr. Laboratory of Insect Ecology, Federal University of Pelotas, Agronomy Department, 96010-900 Pelotas, RS, Brazil. ${ }^{4}$ Ph. D. Laboratory of Plant Health and Homeopathy, Lages Experimental Station of EPAGRI, 88.502-970 Lages, SC, Brazil. Corresponding author: Joatan Machado da Rosa, Ph. D. Laboratory of Entomology, University of Santa Catarina State, Agronomy Department, 88520-000 Lages, SC, Brazil, joatanmachado@gmail.com.
} 
studies are needed to provide a better understanding of the population dynamics of fruit flies in this host.

The periodicity of meteorological factors and its association with population fluctuation have great importance because these factors might affect insect mortality or development, for example, of oviposition, feeding or migration (Hopkins and Memmott 2003). The prediction of the occurrence and intensity of pest populations on agro ecosystems is an important tool for decision-making in an integrated pest management protocol (Aluja et al. 2012).

Despite de high investments on fruit production in Brazil, there is little information about Tephritidae populations in native fruit trees, which could help understand the interaction between plants, pests, and meteorological factors.

Another fact that cannot be taken for granted is that feijoa fruits can be a source of fruit fly multiplication, which can foster the migration of fruit flies to cultivated areas. Therefore, there is a mistaken perception that some native hosts should be eliminated, which may threaten regional agrobiodiversity. This study aimed to characterize assembly and population dynamics of fruit flies in Acca sellowiana orchard at the Lages region, Brazil.

\section{Materials and methods}

The study was conducted from December 2009 to May 2012 in a 16 year old feijoa orchard located at an experimental station of Empresa de Pesquisa Agropecuária e Extensão Rural de Santa Catarina (EPAGRI), Lages, SC, Brazil $\left(27^{\circ} 48^{\prime} \mathrm{S} 50^{\circ} 19^{\prime} \mathrm{W}\right)$ at an altitude of $904 \mathrm{~m}$. The climate in the region is subtropical with rigorous winters and an annual average temperature of $16{ }^{\circ} \mathrm{C}$. The orchard is rectangular and measures 1.5 ha. The plants are interspaced by one meter and spaced five meters between rows. The orchard was surrounded by native grassland, an urban area, a pinus reforestation, and natural forests remnants (Araucaria forest).

The orchard area was divided into four quadrants. In each quadrant, one plant located at its border was selected. Then a McPhail trap was installed 1.8 to $2.0 \mathrm{~m}$ high in branches located in the west side of the tree in order to avoid direct sunlight during the afternoon. Each trap received $250 \mathrm{ml}$ of hydrolyzed protein at $5 \%\left(\right.$ BioAnastrepha $\left.^{\circledR}\right)$. Insect collection, trap cleaning and attractant replacement were done weekly.

Insects captured were separated from the bait solution through a sieve and placed in $80 \mathrm{~mL}$ plastic containers with $70 \%$ ethanol. Then the samples were screened, sexed, identified and counted in a laboratory.

Species identification was done through the observation of wings, thorax and aculeous morphology (Alberti et al. 2012). Flies were put ventrally on a lid; then, the ovipositor was extracted and visualized on a microscope with 40x-100x zoom. The identification of the genus Anastrepha was based on Steyskal (1977) and Zucchi (2000). The other collected genera were identified through keys described by Foote (1980).

Fruit fly assembly was characterized by faunal analysis through the determination of indexes of frequency, constancy, abundance, dominance and species diversity. Frequency was determined by the percentage of individuals of each species compared with total adult flies collected in the traps and classified into the categories infrequent, frequent and very frequent by Thomazini and Thomazini (2002). Constancy for each species was determined by the equation: $C=p * 100 / N$, where $\mathrm{p}$ is the number of collections containing the species and $\mathrm{N}$ is the number of collections characterized in the following categories: constant, accessory, accidental.

Calculations and classifications of abundance (rare, dispersed, common, abundant and very abundant) were done according to Garcia and Corseuil (1998). Species were classified as dominant when frequency values were higher to the limit calculated by the equation proposed by Silva (1993), $\mathrm{LD}=1 / \mathrm{S} \times 100$; where LD: frequency and S: total of species. The diversity index was calculated by the equation proposed by Margalef (1951), DMg = (s-1)/LnN, where s: number of species sampled and $\mathrm{N}$ : total of number of individuals in the sample.

Data on maximum temperature, mean temperature, minimum temperature, precipitation and relative humidity were provided by the meteorological station of Epagri/ Ciram, located at $200 \mathrm{~m}$ from the orchard used in this study at an altitude of 904 masl. Data from collections of $A$. fraterculus adults were used to study population dynamics and correlate it with meteorological data through Pearson's analysis. Moreover, notes were taken about the phenology of feijoa plants. This information was useful for indicating the moment fruit flies were present in the orchard according to plant phenology.

\section{Results and discussion}

During the survey, 2197 Tephritidae adults were collected: 957 were male and 1240 were females (gender ratio of $1: 1.3$ ). Four species were collected belonging to three genera: Blepharoneura, Anastrepha, and Rhagoletis (Table $1)$. The highest catch of females observed in this study was in accordance with results found by Santos et al. (2011) and Nunes et al. (2013). This behavior is probably associated with the need for protein sources presented by females to ensure the fertilization and nutrition of the eggs (Heath 1993).

The genus Anastrepha was the most captured one (Table $1)$, and it was the most representative $(96 \%, \mathrm{~N}=2,189)$. This genus has already been described as a predominant species, mainly in the South and Southeast Brazil: in the states of Santa Catarina (Garcia et al. 2003; Hickel and Ducroquet 2006; Teixeira et al. 2010), São Paulo (Souza-Filho et al. 2000; Raga et al. 2004), Rio de Janeiro (Aguiar-Menezes and Menezes 2000) and Rio Grande do Sul (Garcia et al. 2003; Kovaleski et al. 2000; Scoz et al. 2006).

According to Husch et al. (2012), due to its generalist habit, this species is displacing other Tephritidae from those regions. The preponderance of $A$. fraterculus in this study corroborates the findings of Aguiar-Menezes et al. (2008), who stated that up to two Tephritidae species are predominant in homogenous commercial orchards, where they are usually crop key pests. The high dominance of only one or two fruit fly species, was also observed by other researchers in Brazil (Garcia et al. 2003; Alberti et al. 2012; Husch et al. 2012).

Comparing the attractiveness of different food baits in apple orchards, Teixeira et al. (2010) have observed that 99.9 $\%$ of the total fruit flies captured were $A$. fraterculus. A similar result was found in peach orchards by Scoz et al. (2006), where they collected 1594 specimen of the genus Anastrepha $100 \%$ of them belonged to the species $A$. fraterculus.

Low equitability and high dominance of species were observed in the feijoa orchard (Table 1). Diversity obtained 
Table 1. Faunal indexes of Tephritidae captured in McPhail traps in a feijoa orchard in the municipality of Lages, Santa Catarina, Brazil (2009-2012).

\begin{tabular}{|c|c|c|c|c|c|}
\hline Species & $\mathbf{N}$ & Abundance & Frequency & Constance & Dominance \\
\hline Anastrepha fraterculus (Wiedemann) & 2,189 & Very abundant & very frequent & constant & dominant \\
\hline Anastrepha dissimilis (Stone) & 2 & rare & Infrequent & accidental & non-dominant \\
\hline Blepharoneura sp. & 4 & rare & Infrequent & accidental & non-dominant \\
\hline \multirow[t]{3}{*}{ Rhagoletis blanchardi (Aczél) } & 2 & rare & Infrequent & accidental & non-dominant \\
\hline & & Simpson index & Shannon-winer index & Equitability & Margalef index \\
\hline & & 4.01 & 0.012 & 0.02 & 0.39 \\
\hline
\end{tabular}

N: Number of fruit flies captured.

by the Margalef index was considered low (below 0.5) when compared to the results obtained in other municipalities in Santa Catarina (Garcia et al. 2003; Kovaleski et al. 2000; Zilli and Garcia 2010), which also confirmed the predominance of one species (Table 1).

The high value of the Simpson index and the low values of Shannon-Wiener and equitability indexes (Table 1) indicate a dominance and high frequency of $A$. fraterculus, which comprised $99.6 \%$ of the total flies captured. In similar studies, Dutra et al. (2009) and Santos et al. (2011) found higher Shannon and equitability indexes; however, those studies were conducted in tropical regions where a higher number of specimens of the genus Anastrepha are present.

Two specimens of Anastrepha dissimilis Stone were captured in traps installed in feijoa trees. Nonetheless, $A$. sellowiana is not a host of this species. According to Zucchi (2007), the occurrence of $A$. dissimilis is associated with Passifloraceae fruits. Probably, the capture of $A$. dissimilis is due to the presence of native passion fruits (Passiflora spp.) located near the study area.

A small number of species belonging to genera Blepharoneura and Rhagoletis was also captured (Table 1). According to Condon et al. (2008), Blepharoneura is a Neotropical genus with a high specificity of hosts, and it develops mostly in Cucurbitaceae flowers. Specimens of Rhagoletis blanchardi Aczél that were collected in traps do not have an economic importance in Brazil (Zucchi 2000). Probably, this species is associated with plants of the Solanaceae family, since it was observed to cause damage to tomato fruits, Solanum lycopersicum (Linnaeus, 1753) by Fenilli (1993) in Lages, Santa Catarina.

Hosts of the Myrtaceae family located in forests near commercial orchards are considered to be mainly responsible for sustaining $A$. fraterculus populations throughout the year. Bioecological studies have indicated that the feijoa is one of the most preferred hosts for this fruit

Table 2. Linear correlation indexes calculated between Anastrepha fraterculus captured and meteorological factors: rainfall, minimuam temperature, mean temperature, maximum temperature and relative humidity from December/2009 to May/2012. Lages, Santa Catarina, Brazil.

\begin{tabular}{ccccc}
\hline \multicolumn{5}{c}{ Linear correlation coefficient } \\
Rainfall & Tmean & Tmin & Tmax & $\mathbf{R H}^{\mathbf{1}}$ \\
$(\mathrm{mm})$ & $\left({ }^{\circ} \mathrm{C}\right)$ & $\left({ }^{\circ} \mathrm{C}\right)$ & $\left({ }^{\circ} \mathrm{C}\right)$ & $(\%)$ \\
\hline $0.116^{\mathrm{ns}}$ & $0.2967^{\mathrm{ns}}$ & $0.3296^{\mathrm{ns}}$ & $0.2387^{\mathrm{ns}}$ & $0.1071^{\mathrm{ns}}$ \\
\hline
\end{tabular}

${ }^{\text {ns }}$ Non significant at $5 \%$ significance level. ${ }^{1}$ Relative humidity. fly species (Kovaleski et al. 2000). Besides the availability of intermediate hosts, these authors reported that population density of $A$. fraterculus is highly dependent on climatic conditions, especially in periods with low temperatures in the winter. Climate, according to Berryman (1996), is one of the first factors that determine fluctuation of an insect population. However, in this study, the capture of Tephritidae was not correlated with the climatic variables: temperature, rainfall and relative humidity (Table 2 ).

Studies by Calore et al. (2013) in guava orchards (Psidium guajava L.) have shown that population peaks of Anastrepha spp. occur from January to March and coincide with periods of fruit availability in the orchard. This fact may indicate that the incidence of fruit flies is more dependent on host availability and stage of maturation rather than climatic factors (Fig. 1). Similarly, the influence of temperature and rainfall on Ceratitis capitata (Wiedemann, 1824) in a peach orchard, Prunus persica L. (Batsch, 1801) was not evidenced by Montes et al. (2011).

Analysis of longer time series usually reduces correlations of climatic factors or even eliminates this possibility (Petchey 2000). The climate can favor a population peak, but it is not a determining factor, because there are other physical and biological factors that act together on populations (Hickel et al. 2007). To Souza-Filho et al. (2000) and Ronchi-Teles and Silva (2005), biotic factors, host availability and fruit ripeness are more important for population density than abiotic factors such as climatic conditions.

On the Catarinense Plateau, higher populations of fruit flies occur from December to March, generally accompanied by periods of ripeness of different fruits. Nonetheless, feijoa starts fruit maturation at the end of February and extends until May. Thus, as stated by Kovaleski et al. (2000), it is a fruit tree whose potential as an alternative host is to be explored by fruit flies in the off-season for fruit crops in temperate zones.

Through analysis of capture of fruit flies in McPhail traps for more than ten years, Salles and Kovaleski (1990) have reported that fruit fly populations are higher at the beginning of November until the end of January, with population peaks in mid-December. However, feijoa ripeness occurs late, and in the three-year evaluation, population peaks occurred from February to March and coincided with fruit ripeness.

Natural feijoa stands are a reservoir for fruit flies that can recolonize other temperate fruit trees. Thus, farmers that grow feijoa also have to be aware of migration of flies from apple, pear, peach and other orchards, because female fruit flies seek new oviposition sites and can enter feijoa orchards when fruits are ripening and are highly susceptible to damage caused by fruit flies. 


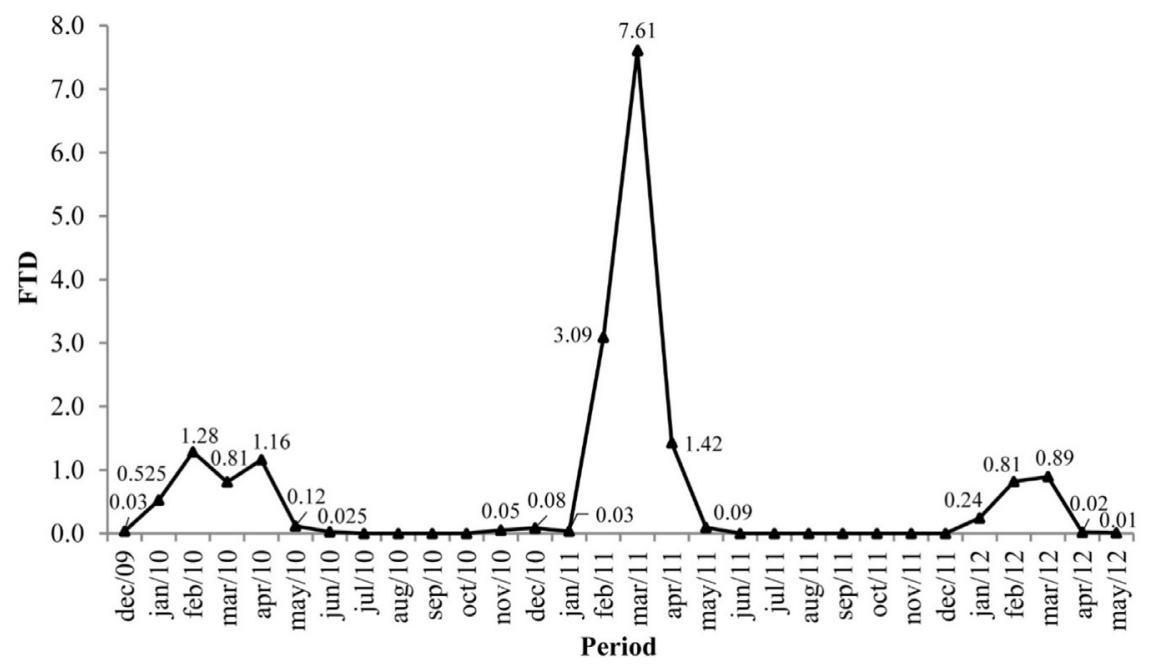

Figure 1. Population fluctuation (FTD: Flies captured per trap per day) of Anastrepha fraterculus captured in McPhail traps between 2009 and 2012 in a feijoa orchard, Lages, Santa Catarina, Brazil.

Population dynamics of fruit flies varies from one year to another, as well as between different orchards in the same period. According to Nora et al. (2000), the absence of fruits is indicative of fruit fly absence; from May to October, no individuals were captured in traps installed on apple and peach orchards that received good management practices.

No flies were captured in the feijoa orchard studied during July, August, September and October in all years evaluated, but flies were captured in May (2010, 2011 and 2012) and July (2010), even in the absence of fruits. This behavior is possibly associated with late fruit drop and presence of decaying fruits in the orchard area.

The presence of $A$. fraterculus in native fruit trees is easily verified and the infestation index is usually high (Garcia and Norrbom 2011). In a study conducted in the state of Santa Catarina, these authors have reported the presence of the insect in 20 species of native and exotic plants from eight botanic families.

Fruit ripeness in wild host plants affects population peaks during its period of occurrence. For example, Cereijeirado-Rio-Grande (Eugenia involucrata DC, Myrtaceae) is indicative of an initial occurrence of $A$. fraterculus in apple orchards. The diversity of wild and cultivated host plants with different fructification periods in Brazil promotes fruit fly reproduction all year round (Nora et al. 2000). According to Bisognin et al. (2013), A. fraterculus is the most adapted species to wild fruit trees and this may be a decisive factor to its predominance in feijoa orchards.

The $A$. fraterculus population varied during the three crops evaluated. However, it was present in most of the sampling period in the feijoa orchard, except between July and November, 2010/2011 (Fig. 1). Population peaks were observed in February/2010, March/2011 and March/2012, which coincided with fruit ripeness.

The puzzling processes that cause change in the number of specimen over time, and also how changes occur, are usually the focus of population ecology studies (Lundberg et al. 2000). Knowledge of population dynamics and timing of higher occurrence of a specific insect species of economic importance is a crucial requirement for establishing an efficient and rational control. It allows more effective management strategies to be planned (Ronchi-Teles and Silva 2005).

In conclusion, it was observed that Anastrepha fraterculus, Anastrepha dissimilis, Rhagoletis blanchardi and Blepharoneura sp. species were captured by McPhail traps in the orchard of Acca sellowiana during the three years evaluated. It was found that $A$. fraterculus is the predominant, most frequent, constant and dominant species. No significant correlation was obtained between climatic factors and population levels of $A$. fraterculus in feijoa orchards.

\section{Acknowledgements}

We are thankful to the geographer Vera Lúcia da Silva from the database sector of Epagri for providing meteorological data. We would also like to thank Brazilian agencies CNPq and FAPESC through CNPq / 562827 / 2010-2 projects, FAPESC / 5288 / 2011-4 - National Research Networks in Agricultural Biodiversity and Sustainable Agriculture - "Repensa: Plants of the future" and The Network Guarani / Serra Geral Conv. FAPEU / FAPESC $16261 /$ 10-2 for granting the financial support.

\section{Literature cited}

AGUIAR-MENEZES, E. L.; MENEZES, E. B. 2000. Rio de Janeiro. pp. 259-264. In: Malavasi, A.; Zucchi, R. A. (Eds.). Moscasdas-frutas de importância econômica no Brasil: conhecimento básico e aplicado. Volume I. Editora Holos, Ribeirão Preto, Brasil. 327 p.

AGUIAR-MENEZES, E. L.; SOUZA S. A. S.; LIMA FILHO, M.; BARROS, H. C.; FERRARA F. A. A.; MENEZES, E. B. 2008. Análise faunística de moscas-das-frutas (Diptera: Tephritidae) nas regiões Norte e Noroeste do estado do Rio de Janeiro. Neotropical Entomology 37 (1): 8-14.

ALBERTI, S.; BOGUS, G. M.; GARCIA, F. R. M. 2012. Flutuação populacional de moscas-das-frutas (Diptera, Tephritidae) em pomares de pessegueiro e maracujazeiro em Iraceminha, Santa Catarina. Revista Biotemas 25 (1): 53-58.

ALUJA, M.; ORDANO, M.; GUILLEN, L.; ANDRULL, J. 2012. Understanding long-term fruit fly (Diptera: Tephritidae) population dynamics: implications for area-wide management. Journal of Economic Entomology 105 (3): 823-826. 
BERRYMAN, A. A. 1996. What causes population cycles of forest Lepidoptera? Trends in Ecology and Evolution 11 (1): 28-32.

BISOGNIN, M.; NAVA, D. E.; LISBÔA, H.; BISOGNIN, A. Z.; GARCIA, M. S.; VALGAS, R. A.; DIEZ-RODRÍGUEZ, G. I.; BOTTON, M.; ANTUNES, L. E. C. 2013. Biologia da moscadas-frutas sulamericana em frutos de mirtilo, amoreira-preta, araçazeiro e pitangueira. Pesquisa Agropecuária Brasileira 48: 141-147.

CALORE, R. A.; GALLI, J. C.; PAZINI, W. C.; DUARTE, R. T.; GALLI, J. A. 2013. Climatic factors in population dynamic of Anastrepha spp. (Diptera: Tephritidae) and Scymnus spp. (Coleoptera: Coccinellidae) in an experimental orchard of guava (Psidium guajava L.). Revista Brasileira de Fruticultura 35 (1): 67-74.

CONDON, M.; ADAMS D. C.; BANN, D.; FLAHERTY, K.; GAMMONS, J.; JOHNSON, J.; LEWIS, M.L.; MARSTELLER, S.; SCHEFFER, S. J.; SERNA, F.; SWENSEN, S. 2008. Uncovering tropical diversity: six sympatric cryptic species of Blepharoneura (Diptera: Tephritidae) in flowers of Gurania spinulosa (Cucurbitaceae) in eastern Ecuador. Biological Journal of the Linnean Society 93 (4): 779-797.

DUCROQUET, J. P. H. J.; HICKEL, E. R.; NODARI, R. O. 2000. Goiabeira Serrana (Feijoa sellowiana). (Série Frutas Nativas 5) Jaboticabal: FUNEP, São Paulo. 66 p.

DUTRA, V. S.; SANTOS, M. S.; SOUZA-FILHO, Z. A.; ARAUJO, E. L.; SILVA, J. G. 2009. Faunistic analysis of Anastrepha spp. (Diptera: Tephritidae) on a guava orchard under organic management in the Municipality of Una, Bahia, Brazil. Neotropical Entomology 38 (1): 133-138.

FAO. 2013. FAO-STAT (Food and Agriculture Organization of the United Nations). http:www.faostat.fao.org. [Review date: June 2016].

FENILLI, R. 1993. Ocorrência de Rhagoletis blanchardi (Aczel) (Diptera: Tephritidae) em tomateiro. Anais da Sociedade Entomológica do Brasil 22 (2): 415-416.

FOOTE, R. H. 1980. Fruit fly genera south of the United States (Diptera: Tephritidae). Science Education Administration, Washington DC, United States, $79 \mathrm{p}$.

GARCIA, F. R. M. 2009. Fruit fly: biological and ecological aspects, In: Bandeira R.R. (Ed.). Current trends in fruit flies control on perennial crops and research prospects. Transworld Research Network, Kerala, India, 35 p.

GARCIA, F. R. M.; CORSEUIL, E. 1998. Análise faunística de moscas-das-frutas (Diptera, Tephritidae) em pomares de pessegueiro em Porto Alegre, Rio Grande do Sul. Revista Brasileira de Zoologia 15: 1111-1117.

GARCIA, F. R. M.; NORRBOM, A. L. 2011. Tephritoid flies (Diptera, Tephritoidea) and their plant hosts from the state of Santa Catarina in southern Brazil. Florida Entomologist 94 (1): 151-157.

GARCIA, F. R. M.; CAMPOS, J. V.; CORSEUIL, E. 2002. Lista documentada das moscas-das-frutas (Diptera, Tephritidae) de Santa Catarina, Brasil. Revista Biociências 10 (1): 139-148.

GARCIA, F. R. M.; CAMPOS, J. V.; CORSEUIL, E. 2003. Análise faunística de espécies de moscas-das-frutas (Diptera: Tephritidae) na região Oeste de Santa Catarina. Neotropical Entomology 32: 421-426.

HEATH, R. R. 1993. Development of attractants for monitoring Caribbean fruit flies (Diptera: Tephritidae). Florida Entomologist 76 (2): 233-244.

HICKEL, E. R; DUCROQUET, J. P. H. J. 2006. Insetos da goiabeiraserrana. Guia ilustrado das espécies. CDRom.

HICKEL, E. R.; HICKEL, G. R.; VILELA, E. F.; SOUZA, O. F. F.; MIRAMONTES O. 2007. Por que as populações flutuam erraticamente? Tantos e tão poucos. E suas implicações no manejo integrado de pragas. Revista de Ciências Agroveterinárias 6 (2): 149-161.

HOPKINS, G. W.; MEMMOTT, J. 2003. Seasonality of a tropical leaf-mining moth: leaf availability versus enemy-free space. Ecological Entomology 28: 687-693.
HUSCH, P. E.; MILLÉO, J.; SEDORKO, D.; AYUB, R. A.; NUNES, D. S. 2012. Characterization of the fauna of fruit flies (Diptera: Tephritidae) in the region of Ponta Grossa, Paraná, Brazil. Ciência Rural 42 (10): 1833-1839.

KOVALESKI, A.; SUGAYAMA, R. L.; URAMOTO, K.; MALAVASI, A. 2000. Rio Grande do Sul. pp. 285-290. In: Malavasi, A.; Zucchi, R. A. (Eds.). Moscas-das-frutas de importância econômica no Brasil: conhecimento básico e aplicado. Volume I. Editora Holos, Ribeirão Preto, Brasil. 327 p.

LUCKMANN, A.; ROSA, J. M. da.; R.; BOFF, P. 2009. Danos e dispersão do gorgulho Conotrachelus sp. em goiabeira serrana (Acca sellowiana) sob monocultivo e ecossistemas "Capões". Revista Brasileira de Agroecologia 4: 1224-1228.

LUNDBERG, P.; RANTA, E.; RIPA, J.; KAITALA, V. 2000. Population variability in space and time. Trends in Ecology \& Evolution. 15 (11): 460-464.

MARGALEF, R. 1951. Diversidad de especies en las comunidades naturales. Publicaciones del Instituto de Biologia Aplicada e Barcelona 9: 15-27.

MMA - Ministério do Meio Ambiente. 2007. Estudo sobre 775 espécies de plantas do futuro. Available at: http://www.mma. gov.br/informma/item/3788-mma-lancara-estudo-sobre-775especies-de-plantas-do-futuro. [Review date: 10 March 2016].

MONTES, S. M. N. M.; RAGA, A.; BOLIANI, A. C.; SANTOS, P. C. 2011. Dinâmica populacional e incidência de moscasdas-frutas e parasitoides em cultivares de pessegueiros (Prunus persica L. Batsch) no município de Presidente Prudente-SP. Revista Brasileira de Fruticultura 33 (2): 402-411.

NORA, I.; HICKEL, E. R.; PRANDO, H. F. 2000. Moscas-dasfrutas nos estados Brasileiros: Santa Catarina. pp. 271-276. In: Malavasi, A.; Zucchi, R. A. (Eds.). Moscas-das-frutas de importância econômica no Brasil: conhecimento básico e aplicado. Volume I. Editora Holos, Ribeirão Preto, Brasil. 327 p.

NUNES, M. Z.; SANTOS, R. S.; BOFF, M. I. C.; ROSA, J. M. 2013. Avaliação de atrativos alimentares na captura de Anastrepha fraterculus (Wiedemann, 1830) (Diptera: Tephritidae) em pomar de macieira. Revista de la Facultad de Agronomía 112 (2): 91-96.

PETCHEY, O. L. 2000. Environmental colour affects aspects of single-species population dynamics, Proceedings of the Royal Society of London. 267 (1445): 747-754.

RAGA, A.; PRESTES, D. A. O.; SOUZA-FILHO, M. F.; SATO, M. E.; SILOTO, R. C.; GUIMARÃES, J. A.; ZUCCHI, R. A. 2004. Fruit fly (Diptera: Tephritoidea) infestation in citrus in the States of São Paulo, Brazil. Neotropical Entomology 33 (1): 85-89.

RONCHI-TELES, B. R.; SILVA, N. M. 2005. Flutuação populacional de espécies de Anastrepha schiner (Diptera: Tephritidae) na região de Manaus-AM. Neotropical Entomology 34: 733-741.

SALLES, L. A. B.; KOVALESKI, A. 1990. Mosca-das-frutas em macieira e pessegueiro no Rio Grande do Sul. Hort Sul, Pelotas 1: 5-9.

SANTOS, M. S.; NAVACK, K. I.; ARAUJO, E. L.; SILVA, J. G. 2011. Análise faunística e flutuação populacional de moscasdas-frutas (Diptera: Tephritidae) em Belmonte, Bahia. Revista Caatinga 24: 86-93.

SCOZ, L. P.; BOTTON, M.; SILVEIRA, M. S.; PASTORI, L. P. 2006. Avaliação de atrativos alimentares e armadilhas para o monitoramento de Anastrepha fraterculus (Wiedemann, 1830) (Diptera: Tephritidae) na cultura do pessegueiro (Prunus persica (L.) Batsh). Idesia (Arica) 24 (2):7-13.

SILVA, N. M. 1993. Levantamento e análise faunística de moscasdas-frutas (Diptera: Tephritidae) em quatro locais do Estado do Amazonas. Tese de Doutorado. Universidade do Estado de São Paulo, Piracicaba, Brasil. 152 p.

SOUZA-FILHO, M. F.; RAGA, A.; ZUCCHI, R. A. 2000. São Paulo. pp. 277-283. In: Malavasi A.; Zucchi R. A. (Eds.). Moscasdas-frutas de importância econômica no Brasil: conhecimento básico e aplicado. Volume I. Editora Holos, Ribeirão Preto, Brasil. 327 p. 
STEYSKAL, G. C. 1977. Pictorial key to species of the genus Anastrepha (Diptera: Tephritidae). Washington: The Entomological Society of Washington. 35 p.

TEIXEIRA, R.; RIBEIRO, L. G; BOFF, M. I. C.; BOFF, P.; ZANARDI, O. Z. 2010. Atratividade de iscas alimentares comerciais para mosca-das-frutas em pomar de macieira. Agropecuária Catarinense 23 (1): 84-88.

THOMAZINI, M. J.; THOMAZINI, A. P. B. W. 2002. Diversidade de abelhas (Hymenoptera: Apoidea) em inflorescências de Piper hispidinervum (C.DC.). Neotropical Entomology 31 (1): 27-34.

THORP, G.; BIELESKI, R. 2002. Feijoas: origins, cultivation and uses. Auckland: David Bateman. 87 p.

ZHANG, M.; WANG, D.; REN, S. X.; FAN, L. Z.; LIU, R. D. 2010. Effects of feijoa cutting diameter on seedling quality. Agricultural Journal 5 (3): 139-141.

ZILLI, G. N.; GARCIA, F. R. M. 2010. Análise faunística e flutuação populacional de moscas-das-frutas (Diptera, Tephritidae) em pomar de Citrus sinensis no município de Chapecó, Santa Catarina. Biodiversidade Pampeana 8 (1): 39-45.

ZUCCHI, R. A. 2000. Lista das espécies de Anastrepha, sinonímias, plantas hospedeiras e parasitóides. pp. 41-48. In: Malavasi
A.; Zucchi R. A. (Eds.). Moscas-das-frutas de importância econômica no Brasil: conhecimento básico e aplicado. Volume I. Holos Editora, Ribeirão Preto, Brasil. 327 p.

ZUCCHI, R. A. 2007. Diversidad, distribución y hospederos del género Anastrepha en Brasil. pp. 77-100. In: HernándezOrtiz, V. (Ed.). Moscas de la fruta en Latinoamérica (Diptera: Tephritidae): Diversidad, biología y manejo. México: S y G Editores. $167 \mathrm{p}$

ZUCCHI, R. A. 2008. Fruit flies in Brazil. Anastrepha species their host plants and parasitoids. Available at: http:www.lea.esalq. usp.br/anastrepha [Review date: 04 October 2017].

Received: 23-Jun-2016 • Accepted: 6-Nov-2017

Suggested citation:

ROSA, J. M. da; NUNES, M. Z.; BOFF, M. I. C.; GARCIA, F. R. M.; BOFF, P.; FRANCO, C. R. 2018. Fruit fly (Diptera: Tephritidae) assemblage in a feijoa orchard in Santa Catarina State, Brazil. Revista Colombiana de Entomología 44 (1): 110115. Enero - Junio 2018. 